\title{
A study on effect of information asymmetry on earning management: Evidence from Tehran Stock Exchange
}

\section{Fatemeh Dadbeh* and Narjes Mogharebi}

Master Student, Department of Financial Management, University of Tehran, Tehran, Iran

\begin{tabular}{l}
\hline C H R O N I C L E \\
\hline Article history: \\
Received January 30, 2013 \\
Received in revised format \\
10 May 2013 \\
Accepted May 152013 \\
Available online \\
June 12013 \\
\hline Keywords: \\
Tehran Stock Exchange \\
Information asymmetry \\
Earning management
\end{tabular}

\section{Introduction}

The general use of accounting information by investors and financial analysts to value firm's stock creates an incentive for earnings management in an attempt to impact short-run stock price (Dye, 1988; Trueman \& Titman, 1988). Prior studies have provided some evidences that managers tend to overstate earnings in periods prior to equity-offerings, such as initial public offers (Aharony, 1993; Tech, 1998a; Larry, 2001, 2004); seasoned equity offers (Tech, 1998b; Rangan, 1998; Shivakumar, 2000); and stock-financed acquisitions (Erickson \& Wang, 1998; Louis, 2004). Furthermore, when the behavior of earnings manipulation demonstrates its slip over time, the stock price and accounting performance revise down in the following years (Sunder, 1997). Teoh et al. (1998a, 1998b), Rangan (1998), Louis (2004) have reported that the degree of earnings management is significantly associated with poor post-issue long-run stock performance. Sloan (1996), Xie (2001) and Chan, et al. (2006) also documented that firm with greater earnings management experience lower subsequent abnormal

*Corresponding author.

E-mail addresses: shdadbeh@yahoo.com (F. Dadbeh) \begin{abstract}
information compared with another. This often happens in transactions where the seller knows the buyer does although the reverse also may happen. Potentially, this could be a knowledge. In this paper, we examine the effect of information asymmetry on earning management. To test the research hypotheses, a sample of 47 companies listed in Tehran Stock Exchange over the period 2002-2008 based on panel data was taken. In these models, the is estimated. Inference is based on significant level or p-value, thus likely that any value or ignificance level of the test is less than 0.05 is rejected at the 95 percent confidence level. The result shows that the information asymmetry has some meaningful effects on earnings
\end{abstract} (c) 2013 Growing Science Ltd. All rights reserved. 
stock returns. Investors are willing to get reliable information and information should be implemented in evaluating the expected values and risks of the investment. However, there is no possibility that managers tend to disclose all the information that they are seeking venture capital. There is too much information available in the financial market and a big portion of the information in the firm level is included in the earnings and dividend announcements.

One of the most important topics in this field is that the management in the firm level might be manipulating the public expectation by it announcements called "the signaling hypothesis", which demonstrate that managers can release their respect about the firm's future by "signaling" in the market, using some actions like earning announcements, dividend announcements, repurchase, merger, etc. If the managers know they could influence investors through expectation to "control" the market, they might do something more to benefit themselves. One condition that mentions this topic in corporate finance is "window of opportunity" (Cheng, 2006).

On the other hand, Dechow et al. (1995) argued that the hypothesis "all firms do not make earnings management" cannot be rejected. Sloan (1996) demonstrated that the stock pattern seems investors "fixate" it on the current earnings, which contain cash components, discretionary accruals and nondiscretionary accruals. Spiss and Affleck- Graves (1995) examined 1975-1989 firms' seasoned equity offers (SEO) sample and found managers took advantage of overvaluation in the market. The managerial purpose can be assumed by the information asymmetry hypothesis- when information asymmetry is high, stakeholders do not have sufficient resources, incentives, or access to relevant information to monitor's actions, and thus gives rise to the practice of earnings management (Schipper, 1989; Warfield et al., 1995).

\section{Theoretical background}

Earnings management may be defined as "reasonable \& legal management decision making and reporting intended to achieve stable \& predictable financial results.” Earnings management is not to be confused with illegal activities to manipulate financial statements \& report results, which do not reflect economic reality. These types of activities, popularly known as "cooking the books," involve misrepresenting financial results. The detection of accounting manipulation (i.e., earnings management) is a topic of considerable interest and importance to a wide variety of interested groups, including investors, auditors and regulators (Fields et al., 2001). However, although extensive academic research has addressed possible causes and consequences of earnings management, the actual measurement of earnings management continues to focus on the model of expected accruals first identified by Jones (1991). Innovations are largely confined to modifications of this approach. One of the first definitions on earnings management was given by Schipper $(1989,92)$, who defined it as: "...purposeful intervention in the external financial reporting process, with the intent of obtaining some private gain”.

A popular and more extensive definition has been given by Healy and Wahlen (1999, 368): "Earnings management occurs when managers use judgment in financial reporting and in structuring transactions to alter financial reports to either mislead some stakeholders about the underlying economic performance of the company or to influence contractual outcomes that depend on reported accounting numbers."

The definitions of earnings management agree on the point that managerial intent is a prerequisite for earnings management, but whether this intent should be opportunistic in nature is not totally clear. Several presentations on earnings management also implement the term in connection with managerial discretion that has the aim to communicate information to investors that is supposedly not opportunistic (e.g. Dechow \& Skinner, 2000 \& Scott, 2003). When examining for whether income smoothing is opportunistic or not, Subramanyam (1996) refers to earnings management only in association with opportunistic behavior but not when managerial discretion is implemented to 
improve earnings persistence and predictability. The view that earnings management is something opportunistic and harmful applied to mislead, at least some stakeholders, is also expressed by the U.S. Securities and Exchange Commission (SEC) and in the earnings management review article by Healy and Wahlen (1999). The intention to mislead someone about financial performance usually requires that earnings management will be difficult to detect.

\section{Information asymmetry}

Information differences across investors (or groups of investors) have been a long-standing concern to securities regulators and at the core of U.S. disclosure regulation (e.g., Loss, 1983; Loss \& Seligman, 2001). Information asymmetry happens when some parties in business transactions access to some information advantage over others (Scott, 2003). Information asymmetry between managers and external information users help managers use their discretion in preparing and reporting accounting information for their own advantage. Although opportunism is limited both by the accounting standards and by independent auditors, there is much recent evidence both in academic literature and the popular press recommending that managers implement their discretion over accounting numbers to achieve private gains. More specifically, this earnings management is an activity where managers implement their discretion to mislead stakeholders about the economic performance of the company or to impact contractual outcomes (Healy \& Wahlen, 1999).

Asymmetric information in financial markets can adopt in different types of adverse selection, moral hazard, or monitoring costs. A lender suffers adverse selection when he/she is not capable of distinguishing between projects with various credit risks when allocating credit. Given two projects with equal expected value, the lender may choose the safest one and the borrower the riskiest. In this context, those undertaking risky activities may also find it convenient to hide the true nature of a project, thereby exploiting the lender's lack of information. By moral hazard, they mean the borrower's ability to use the funds to various uses than those agreed upon with the lender, who is hindered by his lack of information and control over the borrower. As in the moral hazard case, monitoring expenditures are tied to a hidden action by the borrower, who takes advantage of his better information to specify lower-than-actual earnings.

\section{Literature review}

Vernon J Richardson (2000) performed an empirical investigation on the relationship between information asymmetry and earnings management forecasted by Dye (1988) and Trueman and Titman (1988). When information asymmetry becomes high, stakeholders do not have necessary resources, incentives, or access to relevant information to monitor manager's actions, which gives rise to the practice of earnings management (Schipper, 1989; Warfield et al., 1995). Empirical results recommend a systematic relationship between the magnitude of information asymmetry and the level of earnings management in two different settings. Tucker and zarowin (2006) implemented a new technique to study whether income smoothing garbles earnings information or it could improve the in formativeness of past and current earnings about future earnings and cash flows. They measured income smoothing by the negative correlation of a firm's change in discretionary accruals with its change in pre-managed earnings. Applying the approach of Collins et al. (1994), they reported that the change in the current stock price of higher-smoothing firms could contain more information about their future earnings. This achievement is robust for decomposing earnings into cash flows and accruals and for controlling for firm size, growth, future earnings variability, private information search activities, and cross-sectional correlations.

Ewert and Wagenhofer (2005) investigated the usual claim that tighter accounting standards could reduce earnings management. They distinguished between accounting and real earnings management 
and assumed that a standard setter could only impact accounting earnings management by the tightness of standards. In a rational expectations equilibrium model, they reported that earnings quality could increase with tighter standards, but they identified several consequences, which may outweigh this benefit. First, managers increase costly real earnings management because the higher earnings quality increases the marginal benefit of real earnings management. Second, tighter standards could increase rather than decrease expected accounting and total earnings management. Third, the expected total costs of earnings management could also increase and they provided conditions for the occurrence of each of these effects.

Betty \& Harris (1998) reviewed the realization of securities gains and losses to manage earnings in publicly-traded bank holding firms but very little is known about why managers engaged in this behavior. Two possible explanations for earnings management put forth by Warfield et al. (1995) are that managers engaged in this behavior either circumvent accounting-based contracts designed to mitigate agency problems, or reduce information asymmetry. They compared public and private banks' realizations of securities gains and losses to detect how their earnings management varies. They reported that public banks were consistently engaged in more earnings management than private banks were, and that the portion of their current period securities gains and losses attributabled to earnings management was more positively associated with next period's earnings before securities gains and losses. These findings are consistent with earnings management occurring because of greater information asymmetry in public firms, and recommend that earnings management could not necessarily lead to the erosion in the quality of earnings suggested by Levitt (1998).

\section{The proposed study}

Hypothesis: The information asymmetry has some impact on earning management as follows,

$$
\begin{cases}H_{0}: & \rho=0 \\ H_{1}: & \rho \neq 0\end{cases}
$$

where $\mathrm{H}_{0}$ indicates that the information asymmetry has no effect on earnings management and $\mathrm{H}_{1}$ indicates that has a significant effect on the earnings management.

Lev (1988) argued that observable measures of market liquidity could be implemented to identify the perceived level of information asymmetry facing participants in equity markets. Recent theoretical work on the bid-ask spread when he/she suspects that the information advantage possessed by informed traders has increased. Thus, the dealer's spread can be applied to test for an increase in information asymmetry prior to an anticipated information event. The modified Jones model suggested by Dechow et al. (1995) is implemented for earnings management and all variables are deflated by the beginning-of-period total assets. The model employed in the paper is as follows:

$E(A C)_{t}=\alpha_{0}+\alpha_{1}\left(\Delta R E V_{t}-\Delta R E C_{t}\right)+\alpha_{2}\left(P P E_{t}\right)$

where

$E(A C)_{t}=$ Expected normal accrual;

$\triangle R E V_{t}=$ Net revenues in year;

$\triangle R E C_{t}=$ Net receivables in year $t$ less net receivables in year $t-1$;

$P P E_{t}=$ Property plant and equipment at time $t$.

In this paper we use the panel modeling. Consistent with previous studies of earnings management (Healy, 1985; Jones, 1991), the accounting accrual $\left(A C_{t}\right)$ is computed as:

$$
\begin{aligned}
& A C_{t}=\left(\Delta C A_{t}-\Delta C L_{t}-\Delta \text { Cash }_{t}+\Delta S T D_{t}-\text { Dep }_{t}\right) \\
& \text { where } \\
& \Delta C A_{t}=\text { Change in current assets; } \\
& \Delta C L_{t}=\text { Change in current liabilities; }
\end{aligned}
$$


$\Delta$ Cash $_{t}=$ Change in cash and cash equivalents;

$\Delta S T D_{t}=$ Changes in debt included in current liabilities;

Dep $_{t}=$ Depreciation and amortization expense.

Since the hypothesis does not rely on the direction of the managerial accrual, but rather on the magnitude of the accrual adjustments, the dependent variable is based on the absolute value of managed accrual $\left(\left|M A A_{t}\right|\right)$ as follow:

$\left(\left|M A A_{t}\right|\right)=\left|A C_{i}-E\left(A C_{i}\right)\right|$.

Richardson (2000) used both methods to estimate the statistics. He also implemented the closing bid- ask quotes for the last trading of June for each year of the sample as a proxy for the market liquidity. Therefore, empirical model is derived below:

$$
\log |M A A|=\beta_{0}+\beta_{1} B I D A S K+\beta_{2} C F V A R+\beta_{3} S I Z E+\beta_{4} G R O W T H+\varepsilon_{i . t},
$$

where

$\left|M A A_{i}\right|=$ The mean managed accrual ;

$B I D A S K_{i}=$ The mean monthly bidask spread scaled by the average of the bidask prices;

$C F V A R_{i}=$ The standarddeviation of operating cash flows over the test period

divided by the average operating cash flows over the test period

$S I Z E_{i}=$ Natural log of the mean market capitalization for firm $i$ over the test period

Growth $_{i}=$ Net revenues at the end of the test period less net revenues

at the beginning of the test period scaled by net revenues at the beginning of the period

There are 47 firms bid-ask spread data available in the companies listed in Tehran Stock Exchange. The data used in the testing model is extracted from TSE that provide the closing bid- ask prices from 2001 to 2008. The panel modeling is used in this paper.

\section{The results}

Table 1 demonstrates some the basic information on the study.

\section{Table 1}

Descriptive statistics of the variables in the sample

\begin{tabular}{cccccccccc}
\hline Variable & $\mathrm{N}$ & Mean & Median & Std.Dev. & Skewness & Kurtosis & minimum & Maximum \\
\hline IMAA $\mid$ & 329 & 1.14 & 0.86 & 1.17 & 2.31 & 6.16 & 0.01 & 6.46 \\
Ln(|MAA $\mid)$ & 329 & -0.30 & -0.11 & 1.16 & -0.73 & 1.01 & -4.18 & 2.47 \\
BID-ASK & 329 & -444.70 & -280.00 & 16566.7 & 0.64 & 8.06 & -69850.0 & 75768.0 \\
CFVAR & 329 & 0.19 & 0.11 & 0.24 & 2.96 & 11.23 & 0.00 & 1.76 \\
SIZE & 329 & 5.91 & 5.83 & 0.70 & 0.49 & 0.40 & 4.25 & 7.96 \\
GROWTH & 329 & 0.21 & 0.14 & 0.38 & 1.86 & 5.94 & -0.77 & 2.02 \\
\hline
\end{tabular}

In addition, the results of panel analysis of the effect of information asymmetry on earnings management are shown in Table 2.

\section{Table 2}

Panel analysis results

\begin{tabular}{|c|c|c|c|c|c|c|c|}
\hline Parameters & Prob & t.statistic & $\begin{array}{l}\text { Redundant Fixed } \\
\text { Effects Tests }\end{array}$ & $\begin{array}{l}\text { Hausman } \\
\text { Test }\end{array}$ & Results & $\begin{array}{c}\text { R- } \\
\text { Squared }\end{array}$ & $\begin{array}{c}\text { Durbin- } \\
\text { Watson stat }\end{array}$ \\
\hline C & 0.6921 & 0.396369 & \multirow{5}{*}{0.0000} & \multirow{5}{*}{0.48} & \multirow{5}{*}{$\begin{array}{c}\text { Random } \\
\text { effects } \\
\text { model }\end{array}$} & \multirow{5}{*}{0.073249} & \multirow{5}{*}{1.030302} \\
\hline BID-ASK & 0.0000 & 4.700980 & & & & & \\
\hline CFVAR & 0.6770 & 0.416990 & & & & & \\
\hline SIZE & 0.3054 & -1.026472 & & & & & \\
\hline GROWTH & 0.0837 & 1.735230 & & & & & \\
\hline
\end{tabular}

The results show that information asymmetry has effect on earnings management. 


\section{Conclusion}

This paper has examined the effect of information asymmetry on earnings management with bid-ask spread. We have examined the information asymmetry with another models and variables. We have also examined the effect of information asymmetry on firm value, corporate diversification and corporate governance. The results have shown that information asymmetry has effect on earnings management.

\section{References}

Aharony, J., LIN, C. J., \& Loeb, M. P. (1993). Initial Public Offerings, Accounting Choices, and Earnings Management*. Contemporary Accounting Research, 10(1), 61-81.

Beatty, A., \& Harris, D. G. (1999). The effects of taxes, agency costs and information asymmetry on earnings management: a comparison of public and private firms. Review of Accounting Studies, 4(3-4), 299-326.

Chan, K., Chan, L. K., Jegadeesh, N., \& Lakonishok, J. (2001). Earnings quality and stock returns (No. w8308). National Bureau of Economic Research.

Cheng, C. H. (2006). Information asymmetry and earning management in Taiwanese tech industry. Chinese Studies, 8, 99-112.

Dechow, P. M., \& Dichev, I. D. (2002). The quality of accruals and earnings: The role of accrual estimation errors. The accounting review, 77(s-1), 35-59.

Dechow, P. M., Sloan, R. G., \& Sweeney, A. P. (1995). Detecting earnings management. Accounting Review, 72, 193-225.

Dye, R. A. (1988). Earnings management in an overlapping generations model. Journal of Accounting research, 26(2), 195-235.

Erickson, M., \& Wang, S. W. (1999). Earnings management by acquiring firms in stock for stock mergers. Journal of Accounting and Economics, 27(2), 149-176.

Ewert, R., \& Wagenhofer, A. (2005). Economic effects of tightening accounting standards to restrict earnings management. The Accounting Review, 80(4), 1101-1124.

Healy, P. M., \& Wahlen, J. M. (1999). A review of the earnings management literature and its implications for standard setting. Accounting horizons, 13(4), 365-383.

Rangan, S. (1998). Earnings management and the performance of seasoned equity offerings. Journal of Financial Economics, 50(1), 101-122.

Richardson, V. J. (2000). Information asymmetry and earnings management: Some evidence. Review of Quantitative Finance and Accounting, 15(4), 325-347.

Shivakumar, L. (2000). Do firms mislead investors by overstating earnings before seasoned equity offerings?. Journal of Accounting and Economics,29(3), 339-371.

Scott, W. R. (1997). Financial accounting theory (Vol. 3, pp. 335-360). Upper Saddle River: Prentice Hall.

Teoh, S. H., Welch, I., \& Wong, T. J. (1998a). Earnings management and the long-run market performance of initial public offerings. The Journal of Finance, 53(6), 1935-1974.

Teoh, S. H., Welch, I., \& Wong, T. J. (1998b). Earnings management and the underperformance of seasoned equity offerings. Journal of Financial economics,50(1), 63-99.

Teoh, S. H., Wong, T. J., \& Rao, G. R. (1998). Are accruals during initial public offerings opportunistic?. Review of Accounting Studies, 3(1-2), 175-208.

Tucker, J.W. \& Zarovinp, A. (2006). Dose income smoothing improve earning informativness? The Accounting Review, 81, 127-139.

Xie, H. (2001). The mispricing of abnormal accruals. The accounting review,76(3), 357-373. 